\title{
Якість життя хворих із хронічним панкреатитом після хірургічного лікування
}

\section{А. Д. Хруник \\ Івано-Франківський національний медичний університет \\ Quality of life in patients, suffering chronic pancreatitis after surgical treatment}

\author{
A. D. Khrunyk \\ Ivano-Frankivsk National Medical University
}

\section{Реферат}

Вступ. Для оцінки результатів хірургічного лікування хворих із хронічним панкреатитом (ХП) важлива їх власна думка про ефективність проведених лікувальних заходів: наскільки суб'єктивно змінено якість життя (ЯЖ), яка в післяопераційному періоді залежить від виду оперативного втручання.

Матеріали і методи. Проведено аналіз анкет (опитувальник SF-36) 41 пацієнта перед оперативними втручаннями з приводу ХП та після них.

Результати. Після повздовжньої панкреатоентеростомії та дуоденозберігаючих резекцій головки підшлункової залози (ПЗ) ЯЖ хворих краща порівняно з резекційними методиками, після яких в 3 - 2,5 разу нижчі показники за шкалами RP та RE.

Висновок. Показник фізичного компонента здоров'я у віддаленому післяопераційному періоді підтверджує доцільність застосування паренхімозберігаючих операцій у хворих із ХП.

Ключові слова: хронічний панкреатит; якість життя; оперативне втручання.

Abstract

Objective. To estimate the results of surgical treatment in patients, suffering chronic pancreatitis (CHP), their own opinion is significant, concerning efficacy of the treatment measures applied: how much their quality of life (QL) changed subjectively, which depends postoperatively upon kind of the operative intervention performed.

Materials and methods. The answers to questions (questionnaire SF-36) in 41 patients, suffering CHP, were analyzed preoperatively and postoperatively.

Results. As a result of longitudinal pancreatoenterostomy and duodenopreserving resections of pancreatic head the QL is better, than in postresection period, after which the indices are in 3-2,5 times lower in accordance to RP and RE scales.

Conclusion. Index of physical component of health in late postoperative period confirms expediency of application of parenchyma-preserving operations in patients, suffering CHP.

Keywords: chronic pancreatitis; quality of life; operative intervention.

Для визначення результатів того чи іншого способу оперативного лікування важлива власна оцінка хворим ефективності проведених лікувальних заходів: наскільки суб'єктивно поліпшується або погіршується ЯЖ [1]. Показник ЯЖ, пов'язаної зі здоров'ям, узагальнено відбиває ступінь адаптації людини до хвороби і можливість виконувати нею звичні функції, що відповідають ії соціально-економічному стану [2].

Мета дослідження: порівняльна оцінка ефективності лікування за ЯЖ хворих з різними формами ХП у залежності від способу хірургічного лікування.

\section{Матеріали і методи дослідження}

Проведене анкетування 41 хворого із 165 пацієнтів, оперованих з приводу ХП за період з 2010 по 2016 р. Вік опитаних - від 19 до 56 років, середній - $(42,4 \pm 9,4)$ року. Чоловіків було 39, жінок - 2. Терміни перебування хворих у стаціонарі - від 9 до 24 днів, середній термін становив $(14,6 \pm 3,6)$ дня.

Дослідження ЯЖ проводили за допомогою міжнародного опитувальника загального здоров'я SF-36 [3, 4]. Відповіді на запитання отримували шляхом прямого анкетування респондентів через 10 - 48 міс після операціі, середній термін становив $(42,4 \pm 0,9)$ міс. Електронних версій не використовували.

Порівняння показників ЯЖ у різних групах хворих дозволяє виявити вплив окремих факторів на сприйняття пацієнтом своєї хвороби $[4,5]$.

Пацієнтів розділено на три групи: контрольна $(\mathrm{n}=16)$ - практично здорові особи, I (n=30) - хворі із ХП до оперативного втручання; II $(\mathrm{n}=41)$ - хворі із ХП після оперативного втручання. В залежності від виду оперативного втручання хворих групи II розподілено ще на такі групи: IIA ( $\mathrm{n}=13)$ - хворі із ХП, яким виконані дренуючі оперативні втручання на ПЗ (панкреатоєюностомія), IIB (n=21) - хворі із ХП, яким виконані дуоденозберігаючі втручання (операція Фрея, Бернська модифікація операції Бегера), IIC ( $\mathrm{n}=7)$ - хворі із ХП, яким виконано резекційні оперативні втручання на ПЗ.

Результати обробки даних опитувальника SF-36 оцінювали за вісьмома шкалами (показники кожної шкали варіюють між 0 і 100 балами, 100 балів відповідають повному здоров'ю, що відображає фізичне і психічне здоров'я респондентів [6]): фізичне функціонування (Physical Functioning - PF); роль фізичних проблем в обмеженні життедіяльності (Role-Physical Functioning 
- RP); інтенсивність болю (Bodily Pain - BP); загальний стан здоров'я (General Health - GH); життева активність (Vitality - VT); соціальне функціонування (Social Functioning - SF); роль емоційних проблем в обмеженні життедіяльності (Role- Emotional - RE); психічне здоpoв'я (Mental Health - MH).

Статистичну обробку даних здійснювали з використанням пакета прикладних програм «Statsoft Statistica 10.0». Як описові статистичні показники ЯЖ використовували середне значення і стандартне відхилення ( \pm б). Достовірність відмінностей між групами пацієнтів оцінювали з використанням параметричного t-критерію Ст'юдента для незалежних вибірок.

\section{Результати}

На основі аналізу показників ЯЖ у хворих із ХП у цілому виявлено чітку тенденцію до зниження фізичного та психічного компонентів здоров'я (табл. 1). Показник РF у здорових осіб (контрольна група) наближався до максимальних значень - $(94,7 \pm 8,7)$ бала, у хворих групи I він був менший на 51,3\% - $(62,5 \pm 16,3)$ бала $(p=0,0001)$. Хворі із ХП не виконували в повному обсязі своєї звичної роботи, на що вказувало зменшення показників RP та BP, через фізичні проблеми - показник PHs, який є суб'єктивною оцінкою респондентом ступеня обмеження своєї щоденної діяльності. У хворих групи I показник $\mathrm{RP}$ становив $(10,0 \pm 12,5)$ бала, $\mathrm{BP}-(35,1 \pm 25,1)$ бала відносно показників контрольної групи - $(87,5 \pm 20,4)$ та $(86,1 \pm 19,3)$ бала відповідно (p=0,0001).

Пацієнти також низько оцінювали свій психічний рівень здоров'я (MHs), не бачачи перспектив подальшого лікування, часто відчували себе втомленими і знесиленими. Показники RE у групі I були одними із найнижчих - (41,2 $\pm 30,3)$ бала, на 87,3\% менше показників у контрольній групі - $(77,1 \pm 33,8)$ бала $(\mathrm{p}=0,0001)$.

Отже, ЯЖ хворих з ХП низька через прогресування захворювання, що призводить до наростання больового синдрому та недостатності функції ПЗ. Саме тому пацієнти з ХП потребують ретельного обстеження для виявлення ускладнених форм захворювання, щодо яких проводять оперативне лікування. Відтермінування оперативного втручання пов'язане з подальшим загостренням ХП із незворотними фіброзними змінами тканини ПЗ, що спричиняють зниження екзо- та ендокринної функцій з розвитком цукрового діабету. На жаль, значній частині хворих із ХП, які потребують хірургічного лікування, його своєчасно не проводять, тому в них оперативне втручання не може бути ефективним способом лікування. Порівняльний аналіз ЯЖ хворих із ХП у групах I і II за всіма шкалами виявив підвищення показників після проведеного оперативного втручання.

Суттєво підвищилися показники RP - до $(42,5 \pm 27,3)$ бала $(\mathrm{p}=0,0001), \mathrm{BP}-$ до $(62,8 \pm 19,9)$ бала $(\mathrm{p}=0,0001)$ та RE - до $(57,3 \pm 28,6)$ бала $(\mathrm{p}=0,008)$, або відповідно на 35,0, 78,9 та 39,1\% відносно показників у групі I.

Найвищі показники ЯЖ за всіма шкалами були у групі IIA, найнижчі - у групі IIC (mабл. 2). До групи IIA увійшли хворі, яким була виконана повздовжня панкреатоентеростомія - операція Puestow або Partington-Roshelle. Показники ЯЖ в післяопераційному періоді за всіма шкалами в цій групі найвищі, окрім показників GH і VT.
Це відбулося завдяки збереженню клітинної маси, яка виконує екзо- та ендокринну функції ПЗ.

За наявності збільшеної за рахунок фіброзу головки ПЗ необхідне адекватне видалення уражених ділянок, тому виконуються дуоденозберігаючі резекції головки П3 - субтотальна (операція Beger), субтотальна без пересічення ПЗ (Бернська модифікація операції Бегера), локальна резекція головки ПЗ з накладенням повздовжнього панкреатоентероанастомоза (операція Фрея). В нашій клініці перевагу надавали операції Фрея, яка показана для лікування хворих з ХП з вираженим больовим синдромом, множинними стриктурами головної панкреатичної протоки або конкрементами, інтрапанкреатичними псевдокистами у фіброзно зміненій головці ПЗ і гачкуватому відростку, у разі розширення закупореної головної панкреатичної протоки в тілі і хвості ПЗ, а також коли є ускладнення - стеноз загальної жовчної протоки чи дванадцятипалої кишки. Показники ЯЖ у групі IIB і групі IIA були на однаковому рівні за шкалою ВР $(64,1 \pm 22,6)$ бала $(\mathrm{p}=0,004)$ i $(66,3 \pm 18,6)$ бала $(\mathrm{p}=0,009)$ відповідно та за шкалою SF - $(72,6 \pm 23,6)$ бала $(\mathrm{p}=0,04)$ i $(75,0 \pm 18,4)$ бала $(\mathrm{p}=0,06)$ відповідно відносно контрольної групи.

\begin{tabular}{|c|c|c|c|}
\hline Таблиця 1. & Показники & К у хворих (Х & \\
\hline \multirow{2}{*}{ Показники } & \multicolumn{3}{|c|}{ Група хворих } \\
\hline & 1-ша & ॥-га & Контрольна \\
\hline PF & $62,5 \pm 16,3^{*}$ & $71,7 \pm 22,4^{*}$ & $94,7 \pm 8,7$ \\
\hline $\mathrm{RP}$ & $10,0 \pm 12,5^{*}$ & $42,5 \pm 27,3^{*}$ & $87,5 \pm 20,4$ \\
\hline $\mathrm{BP}$ & $35,1 \pm 25,1^{*}$ & $62,8 \pm 19,9 *$ & $86,1 \pm 19,3$ \\
\hline $\mathrm{GH}$ & $47,8 \pm 25,3^{*}$ & $54,5 \pm 16,6^{*}$ & $78,1 \pm 15,3$ \\
\hline VT & $54,4 \pm 17,0^{*}$ & $56,1 \pm 17,9^{\Delta}$ & $86,7 \pm 14,0$ \\
\hline SF & $59,2 \pm 17,6^{*}$ & $74,3 \pm 19,3^{V}$ & $85,8 \pm 3,5$ \\
\hline RE & $41,2 \pm 30,3^{*}$ & $57,3 \pm 28,6^{V}$ & $77,1 \pm 33,8$ \\
\hline $\mathrm{MH}$ & $58,0 \pm 19,2 *$ & $65,0 \pm 16,^{v}$ & $76,0 \pm 15,6$ \\
\hline $\mathrm{PHs}$ & $47,5 \pm 14,8$ & $45,1 \pm 5,9^{*}$ & $51,5 \pm 3,6$ \\
\hline $\mathrm{MHs}$ & $56,4 \pm 13,5^{\star}$ & $59,7 \pm 8,1$ & $63,5 \pm 8,8$ \\
\hline Примітка. & \multicolumn{3}{|c|}{$\begin{array}{l}\text { Достовірні відмінності між контрольною і } \\
\text { групами І чи II. * - p<0,0001; }{ }^{\Delta}-p<0,001 ; \\
- \text { - }<0,02 ;{ }^{\bullet}-\text { p < 0,05. Те ж у табл. } 2 .\end{array}$} \\
\hline
\end{tabular}

\begin{tabular}{|c|c|c|c|}
\hline Таблиця 2. & \multicolumn{3}{|c|}{ 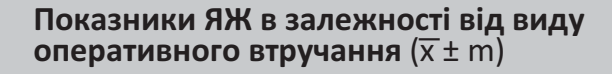 } \\
\hline \multirow{2}{*}{ Показники } & \multicolumn{3}{|c|}{ Групи } \\
\hline & IIA & IIB & IIC \\
\hline PF & $81,5 \pm 16,4^{*}$ & $75,2 \pm 20,9 *$ & $55,7 \pm 30,8$ \\
\hline $\mathrm{RP}$ & $53,8 \pm 28,6^{*}$ & $45,2 \pm 26,9^{v}$ & $17,9 \pm 12,2$ \\
\hline BP & $66,3 \pm 18,6^{*}$ & $64,1 \pm 22,6^{*}$ & $52,0 \pm 10,5$ \\
\hline $\mathrm{GH}$ & $53,2 \pm 12,4^{*}$ & $55,2 \pm 20,4$ & $53,4 \pm 18,8$ \\
\hline VT & $55,8 \pm 12,1^{*}$ & $57,6 \pm 22,5^{\Delta}$ & $58,6 \pm 9,9$ \\
\hline SF & $75,0 \pm 18,4^{v}$ & $72,6 \pm 23,6^{\bullet}$ & $76,8 \pm 15,2$ \\
\hline RE & $64,1 \pm 31,8^{\Delta}$ & $60,3 \pm 27,1^{*}$ & $33,3 \pm 0,0$ \\
\hline $\mathrm{MH}$ & $68,3 \pm 16,4^{\star}$ & $64,8 \pm 18,8$ & $66,9 \pm 5,0$ \\
\hline $\mathrm{PHs}$ & $47,9 \pm 5,2^{*}$ & $46,0 \pm 4,9^{V}$ & $39,4 \pm 8,1$ \\
\hline $\mathrm{MHs}$ & $60,0 \pm 9,5^{v}$ & $59,4 \pm 8,1^{\Delta}$ & $60,5 \pm 3,5$ \\
\hline Примітка. & \multicolumn{3}{|c|}{$\begin{array}{l}\text { Достовірні відмінності між групами IIA і ІІВ. } \\
\text { * - } p<0,0001 ;{ }^{\Delta}-p<0,001 ;-p<0,02 \\
- \text { - }<<0,05 \text {. }\end{array}$} \\
\hline
\end{tabular}


Панкреатодуоденальна резекція, незважаючи на існуючі суперечливі думки про іiі доцільність при ХП, залишається активним методом хірургічного лікування цього захворювання, особливо коли є непрохідність дванадцятипалої кишки. Крім того, техніка оперативного втручання направлена на ліквідацію портальної гіпертензіі за рахунок повного звільнення ворітної і верхньої брижової вен із запального інфільтрату. У пацієнтів з ускладненими формами ХП та підозрою на малігнізацію альтернативи цьому методу не існує.

У хворих групи IIC найбільш низькими були показники за шкалою RP - (17,9 $\pm 12,2)$ бала та шкалою RE - $(33,3$ $\pm 0,0)$ бала, що в $3-2,5(\mathrm{p}=0,006)$ та $1,9-1,8(\mathrm{p}=0,02)$ разу менше у порівнянні з групами IIA та IIB відповідно і свідчить про значне обмеження життєдіяльності через фізичні та емоційні проблеми.

\section{Обговорення}

У хворих з ХП після оперативного втручання покращується самопочуття і вони можуть більш повно і якісно виконувати свої щоденні обов'язки. Це стосується не тільки їх фізичного самопочуття (PHs), а й емоційного стану (MHs). Після операції знижується ступінь впливу больового синдрому на повсякденну діяльність хворих. «Якість життя, пов'язана зі здоров'ям» у хворих групи II не повертається до рівня практично здорових осіб через те, що функція заміщеної фіброзом тканини ПЗ не відновлюється. Хворі групи II мають перебувати на диспансерному обліку, дотримуватися дієти, постійно отримувати замісну терапію.

Вибір оперативного втручання при ХП індивідуальний для кожного пацієнта. Основними факторами, що визначають спосіб оперативного втручання, $є$ розмір головки ПЗ та діаметр головної панкреатичної протоки, наявність ускладнень з боку сусідніх органів (непрохідність дванадцятипалої кишки, портальна гіпертензія, механічна жовтяниця). В нашій клініці розроблено алгоритм хірургічної тактики у хворих з ХП із протоковою гіпертензією на основі клініко-інструментальних та морфологічних даних у передопераційному періоді [7], якого ми дотримувалися.

Збереження функціонального резерву ПЗ та зникнення болю в животі у хворих підгрупи IIA $€$ одним з основних критеріїв хорошого результату. Проте дана операція має обмежені показання - ізольований вірсунго- літіаз, розширення головної панкреатичної протоки без стенозу і закупорки дрібних гілок, відсутність значної фіброзної дегенерації головки ПЗ, ХП з атрофією головки ПЗ і вірсунгоектазією.

Отримані нами результати фізичного компонента здоров'я (РНs) в післяопераційному періоді згідно з опитувальником SF-36 були значно нижчі в групі IIC - (39,4 $\pm 8,1)$ бала, ніж у групах IIA і IIB - відповідно $(47,9 \pm 5,2)$ і $(46,0 \pm 4,9)$ бала $(\mathrm{p}=0,009)$, що вказує на гірші результати застосування резекційних методик та доцільність ширшого використання паренхімозберігаючих операцій, до яких належать дренуючі та дуоденозберігаючі оперативні втручання.

\section{Висновки}

1. ЯЖ у хворих з ХП низька через прогресування захворювання, що призводить до наростання больового синдрому та недостатності функції ПЗ і потребує індивідуалізованого вибору оперативного втручання для кожного пацієнта.

2. Показник фізичного компонента здоров'я (PHs) у віддаленому післяопераційному періоді підтверджує доцільність білыш широкого використання паренхімозберігаючих операцій у хворих з ХП.

\section{References}

1. Vasile D, Ilco A, Popa D, Belega A, Pana S. The surgical treatment of chronic pancreatitis: a clinical series of 17 cases. Chirurgia (Bucur). 2013 Nov-Dec; 108:794-9.

2. Leshchenko CI, Monoharova NYe, Polishchuk VV. Pokaznyky iakosti zhyttia u khvorykh na idiopatychnyi interstytsialnii pnevmonii. Ukr pulm zh. 2008; 1:17-21. [In Ukrainian].

3. Ware JE Jr, Sherbourne CD. The MOS 36-Item Short-Form Health Survey (SF-36): I. Conceptual Framework and Item Selection. Med Care. 1992 Jun; 30(6):473-83.

4. Novik AA, Ionova TI. Rukovodstvo po issledovaniyu kachestva zhizni v meditsine. 2th ed. YuL Shevchenko. Moskva: OLMAPRESS; 2007. 313 p. [In Russian].

5. Belyakova SV, Belousova EA. Kachestvo zhizni bolnyih hronicheskim pankreatitom $\mathrm{v}$ Moskovskoy oblasti. Almanah klinicheskoy meditsinyi. 2015; 40:64-71. [In Russian].

6. Ware JE, Kosinski M, Dewey JE. How to Score Version Two of the SF36 Health Survey. QualityMetric, Incorporated RI, 2000b.

7. Shevchuk IM, Khrunyk AD. Algoritm hirurgichnoyi taktiki u hvorih na hronichniy pankreatit iz protokovoyu gipertenzieyu na osnovi klinikoinstrumentalnih i morfologichnih danih. Informatsiyniy list № 1022013; Kyiv. 2013. 2 p. [In Ukrainian]. 